\title{
Closeted Homosexuality has its Reasons
}

\author{
Daniel Otero* \\ English Teacher, Investigative Paper, The Silver Beach High School, Hui-dong County, China
}

*Corresponding Author: Daniel Otero, English Teacher, Investigative Paper, The Silver Beach High School, Hui-dong County, China

\begin{abstract}
As men and women began coming literally 'out of the closet' in Western societies during the 1990s, men/women had to hide their sexual identities for generations. The results were harsh and profound when exposed. But it's important to illustrate these tendencies, demonstrate why these famous personalities who were/are homosexual and why millions still choose to stay hidden. Given their precarious positions in society. For these circumstances, it's important to show through this paper why closeted homosexuality still has a purpose. As most like to view themselves as liberals in the educational fields and in the acceptance/tolerance of different ideas, until it doesn't affect their families. Therefore, nobody can say whether it's acceptable or not. But one thing is certain, when a person is gay, it shouldn't matter their background or profession. What matters if they can do their job properly and function normally in everyday society. This is the most important fact to demonstrate. This paper will illustrate closeted homosexuality through periods in history, contemporary times and in different countries.
\end{abstract}

Keywords: 'Out of the Closet', Western Society, Homosexual, Tendencies, Demonstrate, Accept, Gay, Background and Profession.

Abbreviations: N.U.F.E. - Nanjing University of Finance \& Economics; L.G.B.T.Q. - Lesbian-Gay-BisexualTransgender \& Queer; L.G.B.T. - Lesbian-Gay-Bisexual \& Transgender; P.T.S.D. - Post-Traumatic Stress Disorders; S.A.R. - Special Administrative Region (applies to places like: Hong Kong \& Macao; P.R.C. People's Republic of China; C.A. - Central Africa; U.N. - United Nations; U.S. - United States; U.K. - United Kingdom; N.I. - Northern Ireland; N.Z. - New Zealand; S.A. - South Africa; C.R. - Costa Rica; M.E. - Middle East; S.E.A. - South East Asia Regional

\section{INTRODUCTION}

Closeted homosexuality had its reasons in the past. For one, in many of the ancient societies, to be labeled or marked as a homosexual could easily cost a person his or her life.

People were made to banish, ostracized, executed by stoning or hanged and burned to death according to the ideas of the Catholic Church.

But these practices of savagery stopped at the beginning of the $19^{\text {th }}$ Century, when laws were implemented. Men in the majority of cases were made to do prison time.

In countries like the United Kingdom, homosexuals were called sodomites. The term used across Europe was to 'keep a boy'. Prison terms could be two years of more for the crime of 'buggery'. These terms aren't used anymore; however, there's still a stigma attached to being gay. This word which came to mean 'happiness' at one point was suddenly changed to reflect on somebody of homosexual nature.

Most homosexuals were kept in hiding for the fear of persecution and death. Even with the laws implemented in the U.K. (United Kingdom), there were and are still hate crimes committed against people for identifying themselves as $L G B T Q$ (Lesbian-Gay-Bisexual-Transgender \& Queer).

Therefore, this minority community had to fight for their rights to live, subsist and love. To be one with the rest of society; however, it hasn't been easy and in a world with 195 countries and there are only 30 which will accept their lifestyle.

How about the other 165 countries? In the majority of cases, either their hide their sexuality or if they go public, it's at the risk of the following: harassment, beatings, torture, rape, mutilation and murder. 
Several Muslim countries in the Middle East and Africa have the harshest laws against homosexuality. They can implement medieval practices handed down from the Sharia law, this is often the stoning to death and so forth.

While we may think about 'Western society' as light years ahead with homosexual rights. It wasn't so long ago that men went to prison for the crime of gay love. Yes, this practice was practically stopped after the 1950s.

Such example is in the lines below...

In the past, great men like Oscar Wilde ${ }^{1}$ was one of those men to pay the price with his career and he did prison time for buggery. What a witty man, with a promising career brought to an end by hate, hypocrisy, indifference and bigotry in elitist England.

What happened to the tolerance of the Ancient Greeks?

For one, Christianity and other religions changed the rules and suddenly it was a 'sin' to be men with men or girls with girls.

\section{Methodology}

What started this investigation about closeted homosexuality and my views since living in China?

It honestly and innocently started while working as teacher and observing a male-chauvinist society who wouldn't accept them (gays in general). How easily they could be ostracized in the day to day events, and even when dealing with teachers who still considered homosexuality a mental illness. Something which pretty much you're born with and indicates your gender.

At the time, as I taught English here in China, I approached the Nanjinger magazine based in Nanjing. Here was when I pitched the story, since I freelanced for them between 2011 and 2014. Quickly the story was shot down, and I quote the words of the Editor, "China is not ready for such stories. This is still a conservative culture about the issue and it wouldn't go well!"

I argued the point via email, 'that times were changing and stories like these were appearing in periodicals all over China. That China was becoming more tolerant with this issue.' To no avail, I was turned down.

A year later, when I had left the Nanjinger. I again investigated further about the homosexual population in China. This was by 2015 . When by then, I wrote an article and the story was accepted by the Beijing Global Times Metro section, and it was actually my second story published with them. By August 10, 2015 the piece titled, 'Learning to accept gay love in China' was posted. It exposed a little about the history of Chinese homosexuality through the Song \& Tang Dynasties. Focusing especially on the current events happening in China and in the end, I was able to interview and quote one of my former students who is gay. As he expressed the following words, "My ideal 'freedom' for a gay person in China is that they dare say out loud who they love and hold their lovers' hands and kiss on the street, regardless of others' reactions." 2

This was one of my proudest moments, because I fully understood that articles like these would bring homosexuality 'out of the closet' to help a population of over 50-million Chinese homosexuals become much happier in their lives.

It doesn't mean that homosexuality is not without criticism. But more and more stories are coming out in support of the gay community.

In Chengdu, I was able to also focus on another piece. Thanks to the opportunities given to me while writing for Future Handling in Hong Kong (2016 - Present). This piece dealt with the lesbian community in this city, located in Sichuan Province. ${ }^{3}$

There was another story I approached with gusto, when I wrote about the $L G B T$ society in Shanghai and how this city was 'light years' ahead of most cities in China; by tolerating them more than any other city in the whole of the country. ${ }^{4}$ But it didn't mean that the authorities wouldn't crackdown on them if 'they got out of hand'. However, what is to get out of hand? When a person clubs, kisses, hugs and dances with other men. And still, it was liberalizing to see the annual 'drag queen' competitions hosted in certain gay pubs. These were examples that times were certainly changing! 
With this said, I was able to write about these topics in three-generic essays.

Therefore, developing a dream which has become today a reality. To write about a topic in support, which is closest to the my heart; and exposes the reality faced by gays in the past in Europe and what was happening presently in China. And not only, has it happened frequently around the world. Here is the title of this project came to be, 'Closeted homosexuality has its reasons'.

China does have problems accepting homosexuality, but little by little is becoming more tolerant and accepting them into the mainstream culture. From soap operas to people bravely coming out. This certainly indicates a Carpe Diem (Seize the day) attitude and new day in this country!

\section{History of Homosexuality And FAmous 'Closeted' Men}

Everything came to an end with Greek culture's liberalism to a much tougher and meaner world with the middle or dark ages (Medieval times lasted between the $5^{\text {th }}$ to the $15^{\text {th }}$ Century, almost 1,000 years). This period in history which came to signify wars, genocides, religious wars, diseases, hunger, colonialism and suffering brought two main religions that would change humanity forever: Christianity and Islam.

What was once allowed to be practiced freely--was outright banned for centuries. The druids virtually disappeared in Ireland and homosexuality in Europe was a closely guarded secret. At the risk, if and when caught, faced a very public and humiliating trial. If the accused couldn't get out of it, he or she faced the possibility of mutilation and in the majority of cases, death!

In the Middle Ages if you wanted to slander a man's reputation, you could spread the rumor that he was 'keeping a boy' and that would certainly get the attention of the local authorities and the Holy Roman Catholic Church.

However, it was the same Catholic Church that for centuries has allowed the problems of pedophilia to continue unchecked, hidden from the public eye and not correctly prosecuted in modern times.

The Italian artist Botticelli kept his private life a closely guarded secret. Since he wasn't immune to be prosecuted if he was caught 'keeping a boy'.

This law and double standard didn't apply to everybody. Only those whom the Catholic Church wanted to prosecute, deemed worthy to condemn, torture and kill through what they called, 'the flames of purification'. This cruel method was to place a person in a pyre and burn them to death!

It was no wonder, why the long-arm of the Catholic Church was quite feared in Europe!

Artist like $d a$ Vinci were believed to also be closeted. This was something which has been debated through the centuries; especially when he painted his masterpiece, La Gioconda. Historians have debated who was the woman in the picture. Was she a noble woman from that period? But many have argued and suggested it was Leonardo himself practicing being a transvestite; painted while he held up a mirror and did his self-portrait. We will never know, but it was certainly safer for the artist's sexuality never to come out! ${ }^{6}$

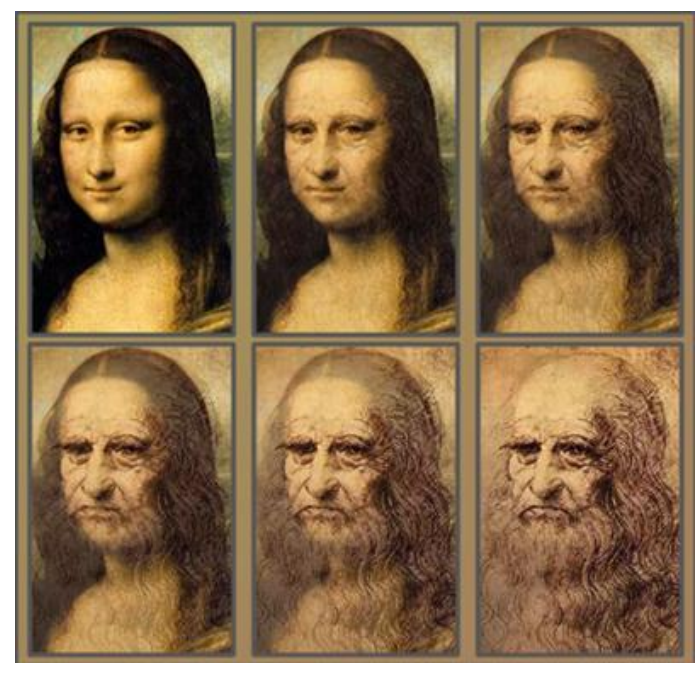

Cultstories.altervista.org ${ }^{7}$ 


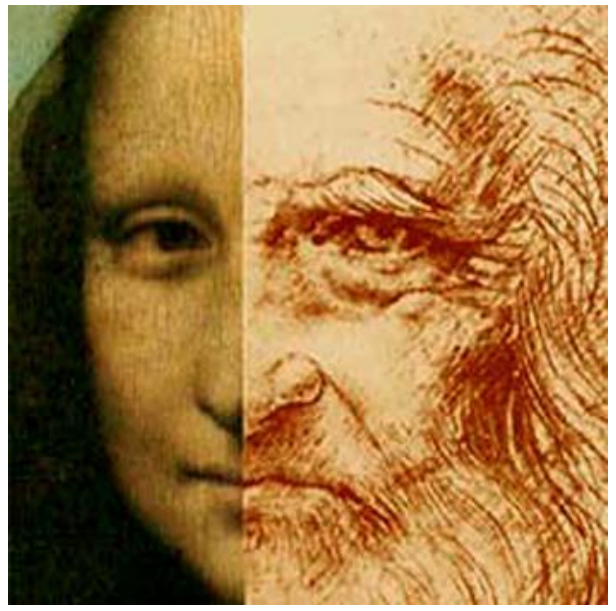

Fotoartearchitettura.its

Michelangelo at the time of his death, which has been the cause of great speculation, also led a secretive-double life. The person who was there at the last moments before his death, assistant or apprentice, who may have been as well his young lover.

This was the common norm across Europe and a well known 'public secret' which could ruin any career, destroy it, if forgiven--prison time. However, these were the 'best' options. The last one was to die a torturous-agonizing death that could last for minutes by the flames, hours on the rack, days or weeks! Depending on the damage and information the institution of the time wanted.

Oscar Wilde was indeed one the biggest tragedies in our modern era and the biggest injustice done to a person for loving another. What we take for granted today as a given and part of our rights, wasn't so a century before.

Shakespeare, the greatest dramatist may have been another casualty in the liberalization of sexuality. Theories have surfaced and resurfaced about his attraction to men and that he only married to keep this part of his life well hidden.

But definitely there is a greater difference for Shakespeare, dealing with the fear of his time. Medieval England would have cost Shakespeare his life if caught or displayed any acts of homosexuality. ${ }^{9}$ Versus Wilde, who was 'luckier' several centuries later to have ended-up in prison and have his life 'spared'.

In the case of Wilde, once he was discovered, his career was basically over and the newspapers at the time were the first to destroy the man's reputation. With bringing him down at the height of his popularity didn't only mean being banned from the dramatic-playhouses. It was a prison term of two to three years, depending on the severity of the act! Not only destroying the man's life, but that of his lover.

Once their prison sentences were completed, they weren't allowed to communicate ever again. It was established as the law of the land and what we think as inhumane, was the common practice at the time.

Thomas Edward Lawrence's situation was that he lived his life closeted for his entire life. There's little fact which states if Lawrence had had a female lover. The problem with this war hero came with the price of fame, which quickly destroyed him. And what he did was to change his identity and while in India, he became Airman Ross. This didn't change the fact, that Lawrence possibly was suffering from present-day P.T.S.D. (Post-Traumatic Stress Disorders). On top of this, from his torture in the city of Dera'a, Arabia (the Arab Campaigns of World War I) he developed a fixation for masochism. ${ }^{10}$ Something not entirely proven, but discussed amongst those who knew him all too well and historians.

David Bowie and Elton John exposed themselves to a public a little less threatening or menacing. This was according to the right moment and generation. However, they weren't ready to fully come out as homosexual, as was the case of Sir Elton John. Therefore, when interviewed, they preferred to state or identify themselves as bisexual. It was less risky on their careers. 
Bowie was forward because of the period in history in which he lived. Nonetheless, we can still admire him, but it was Botticelli who really took the risk and lived the way he wanted. Hidden from the public eye, it was still the perfect way to live in secrecy, happily and being honest with himself. Although, he had to do it in the privacy of his own home.

The psychological effects on these men and women living in hiding must have been overwhelming and traumatic. Because most had to live a double-life just to survive.

\section{Closeted Homosexuality in Africa, Asia \& The Middle East}

One thing that is strikingly different from continent to continent is homosexuality. The truth is simple enough to see, 'closeted homosexuality' will depend on one's country of birth. What's tolerated or not!

For most, in Western societies, it's the risk of scandal and losing it all!

And it is know in East Asian societies the risk is to be ostracized permanently. However, even that is changing. Check what happened to Japan back in 2017, when through a surprising and landmark decision, the Japanese government finally allowed same-sex unions. Something which never happened before and still highly contested by this conservative society. But consider this for a moment, today you can marry in Japan with your homosexual partner. It has taken far longer in Japan to accept the crime of rape, than to accept homosexuals as human beings.

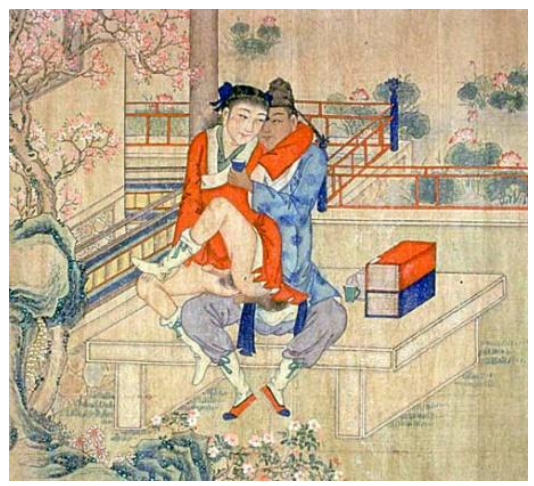

Two young Chinese men drinking tea and having sex. The "submissive" partner would be lighter in skin colour to reflect his femininity. ${ }^{11}$

For China, the reality is that government and institutions are liberalizing the act. It is not accepted, but it's tolerated, once it doesn't go against national policy. When you have a population of over 50+ million gays (figures can go as high as $70+$ million, nobody is certain), you have to consider the future alternatives. ${ }^{12}$ Therefore, I don't doubt that in a less than a decade the law will change in the People's Republic of China (P.R.C.) and Hong Kong, S.A.R. (Special Administrative Region) to allow homosexuals to marry and later think about adoption. This was something that would have made singer and gay icon, Leslie Cheung proud. ${ }^{13}$ That finally gays are being accepted into the mainstream. They may suffer discrimination, but not hate crimes or the violence perpetrated in other countries. However, for a country which shies away from controversy; it has been said that $80 \%$ of homosexual men will marry out of social pressure and stay silent for the rest of their lives. ${ }^{14}$

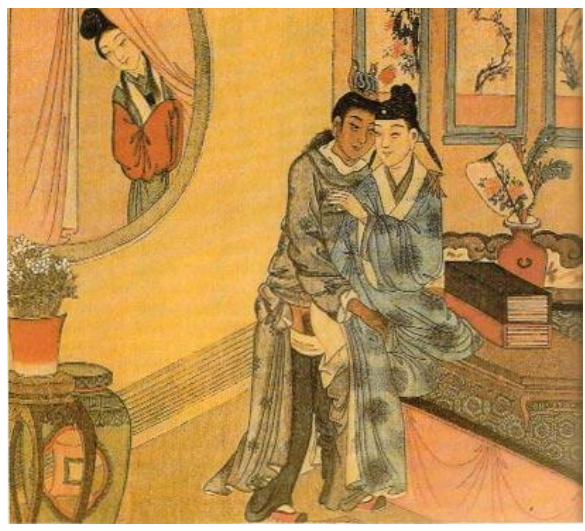

A woman spying on two male lovers ${ }^{15}$ 
In certain areas of Central Africa (C.A) and the Middle East (M.E.), being gay can cost a person his or her life! From stoning, people will be easily mutilated, their genitals ripped-off and hung for the whole world to see. For those people, it's far more important being 'closeted' and staying in secret, than exposing themselves. It is better in this contemporary culture to live the image of outstanding citizen-than to be exposed. The risk is far too great, not only being shunned, but raped and put to death!

\section{CONCLUSiONS}

Closeted homosexuality does have its reasons. And at the same time, many who closet themselves, still suffer great mental anguish while hiding the truth. Pressure by most of society through: colleagues, friends and family members to get married. Truth has eventually a strange way of coming out.

In traditional societies like China, most parents are constantly pushing for their child to get married after their study years. Which in China, it's usually after 24-years of age. Then, soon after, whether they can deal with the economic burden or not, there's that extra-pressure to have a child.

It is my conclusion that $90 \%$ of homosexuals will stay hidden out of fear, reprisals and basic mistrust to not get hurt. It is the reality in an often unfair and prejudicial world. For the most part, there's the hidden danger to get shunned/disowned by family members, rejected by friends, ignored by workmates, fired from jobs and persecuted by their respective governments.

In many cases with male-chauvinist societies, there's a fear in which 'coming out' may literally 'gut' a person's professional chances. That's one of the biggest reasons why homosexuals take so long to come out; especially when they are artists and their careers are on the rise.

If not, could a person like Ricky Martin ${ }^{16}$ survived the onslaught if he had come out in his 20s? I honestly don't think so, given society's prejudices, versus when he was already an established artist in his 40s and there wasn't the fear of backlash or loss.

But on a positive note, times or people have certainly changed. If you can't believe me. Take actors like Rock Hudson ${ }^{17}$ or Liberace ${ }^{18}$, who had to keep their homosexuality a secret in Hollywood for decades. Compared presently to a Ellen DeGeneres or Ellen Page. Well, in truth, it was a public secret amongst the Tinsel town elite when people like Hudson or Liberace lived. It was only towards the end of their lives when the truth finally came out.

However, along countries in the Middle East (M.E.), Southeast Asia Regional (S.E.A.) and Central Africa (C.A.) from east to west--there's the risk of torture, mutilation and death! This has been stated over and over previously. For these reasons, homosexuals will stay closeted at the risk of their lives.

In Western societies homosexuality took tremendous leaps forward after the 1960s! That is why, today we have a small amount of countries who tolerate same-sex unions. From this point, with gay marriages, also began the process of adoption to start a family in different countries, etc.

There are 195 recognized countries across the world by the United Nations. Out of those, a little over $15 \%$ allow same-sex marriages/unions, yes, 30 nations which currently have accepted it and here are the following:

- United States (U.S.)

- United Kingdom (U.K.) (Accepted in three countries, but not in Northern Ireland) (N.I.)

- Canada

- Australia

- France

- Germany

- Italy

- Spain

- Norway

- Sweden

- Finland

- Denmark 
- Iceland

- Belgium

- Austria

- Netherlands (First country in the world to accept same-sex unions)

- Luxembourg

- Malta

- Greece

- Portugal

- Ireland

- $\quad$ New Zealand (N.Z.)

- South Africa (S.A.)

- Mexico (Will depend on which State legislation is recognized)

- Costa Rica (C.R.) (Waiting this year for reformation of the law and acceptance)

- Argentina

- Uruguay

- Colombia

- Brazil

- Taiwan (Currently awaiting to amend the law and accept same-sex unions) ${ }^{18}$

At the rate for social acceptance of homosexuality around the planet. It ought to take humanity another 60-years for the majority of the world to accept gay love. ${ }^{19}$ Therefore, hopefully leaving the past behind on closeted homosexuality and the prejudices millions of homophobic people carry with it.

\section{ACKNOWLEDGEMENTS}

This one is dedicated to Jia Chen (Cyrus), one of my best students in Nanjing University of Finance \& Economics (N.U.F.E.). As a student he was never too afraid or shy to say his say, in spit of controversy. One of my greatest supporters through the highs and lows in the last six years of my life. Thank you, kind sir!

The next one is to my friend Liu Meng, one of the best Editors I have ever worked for. We cooperated magically for three years at the Beijing Global Times Metro section (2015 - 2018). She wasn't only my Editor, but my Teacher. Yes, Editor and Teacher, with the first letters capitalized; because till this day, I'm extremely proud of her! Much oblige for everything you did during that time. Overall, I have say, we wrote some pretty neat stories. Always open and supportive of my ideas. I'll never forget!

\section{REFERENCES}

[1] Cowburn, Ashley. (19 October 2016). "Government to pardon thousands of gay men under 'Alan Turing Law'". The Independent.

[2] Otero, Daniel. (August 10, 2015). "Learning to accept gay love in China”. Beijing Global Times Metro.

[3] . (August 21, 2017). "Lesbianism in China: No, not in my city!". Future Handling: Hong Kong, S.A.R. China. Retrieved from https://futurehandling.com/2017/08/21/lesbianism/

. (January 29, 2018). "Shanghai's LGBT community and its future". Future Handling: Hong Kong, S.A.R. China. Retrieved from https://futurehandling.com/2018/01/29/shanghai-an-example-for-thelgbt-community/

[5] Hudson, Mark. (14 February, 2016). "Before Bowie, there was Botticelli". The Telegraph: U.K. Retrieved from https://www.telegraph.co.uk/art/what-to-see/before-bowie-there-was-botticelli/Isaacson, Walter (2017). Leonardo da Vinci. New York: Simon \& Schuster.

[6] Chezzi, Annachiara. (N.D.). "La Gioconda, il bottino piu ambito (Mona Lisa, the most coveted loot". Cult Stories. Altervista. Retrieved from http://cultstories.altervista.org/gioconda-bottino-ambito/

[7] Campanella, Paola. (2019). "Si parla di arte... Le domandi piu frequenti: 9modo vederi La Gioconda (If you talk about art... The frequently asked questions: 9 ways to see the Mona Lisa). Foto Arte Architettura: Italy. Retrievedfrom https://www.fotoartearchitettura.it/9-modi-di-vedere-la-gioconda/le-domande-piufrequenti.html 
[8] Jungman, Robert E. (January, 2003). "Trimming Shakespeare's Sonnet 18". ANQ: A Quarterly Journal of Short Articles, Notes and Reviews. ANQ. 16 (1): 18-19.

[9] Letter to W.F. Stirling, Deputy Chief Political Officer, Cairo, 28 June 1919, in Brown, 1988.

[10] Kinsey Institute. (20 February, 2005). "Two young Chinese men drinking tea and having sex. The "submissive" partner would be lighter in skin color to reflect his femininity" (Qing dynasty, $18^{\text {th }}-19^{\text {th }}$ c.). Bloomington, Indiana.

[11] Harris, Dan. (July 5, 2013). Homosexuality in China. Good People. Retrieved from https://www. chinalawblog.com/2013/07/homosexuality-in-china.htmlUnknown - Louis Crompton, Homosexuality \& Civilisation, Cambridge/MA; London, 2003, p.232.

[12] Otero, Daniel. (June 26, 2018). "The middle-age generation and the high rate of suicide". Future Handling: Hong Kong, S.A.R. China. Retrieved from https://futurehandling.com/2018/06/26/suicide-and-prevention/

[13] Bram, Barclay. (December 14, 2016). China's 'Tongqi': The Millions of Straight Women Married to Closeted Gay Men”. LGBT. Broadly. Retrieved from https://broadly.vice.com/en_us/article/ 43gdpp/chinas-tongqi-the-millions-of-straight-women-married-to-closeted-gay-men

[14] "Yep, He's Gay: Ricky Martin Comes Out of the Closet". Rolling Stone Music. Rollingstone.com (29 March 2010).

[15] Hofler, Robert. The Man Who Invented Rock Hudson: The Pretty Boys and Dirty Deals of Henry Willson. New York: Carroll \& Graf, 2005, pp. 248-250; Oppenheimer, Jerry and Vitek, Jack. Idol Rock Hudson: The True Story of an American Film Hero. New York: Villard Books, 1986, p. 55.

[16] "BEHIND THE CANDELABRA; The Book, The Movie". Early Word. March 20, 2013.

[17] "Taiwan Court Rules Same Sex Marriage Legal in Asia First". NBC News. May 24, 2017.

[18] Marusic, Kristina. (July 11, 2017). "No, These Countries Actually DON'T Have Same-Sex Marriage: Many countries we think as gay paradises lag behind when it comes to marriage." Logo: New Now Next. Retrieved from http://www.newnownext.com/gay-marriage-worldwide/07/2017/

\section{AUTHORS' BIOGRAPHY}

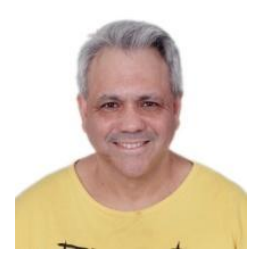

Daniel Otero, A New Yorker who has been living in China for the past nine years. He's a freelance writer and ESL teacher. Former member of the military with extensive travel and living experiences throughout different countries. Lover of life, good food, travel, writing and dealing with social issues.

Citation: Daniel Otero. "Closeted Homosexuality has its Reasons ". International Journal of Humanities Social Sciences and Education (IJHSSE), vol. 6, no.4, 2019, pp. 18-25. doi: http://dx.doi.org/10.20431/23490381.0604004 .

Copyright: (C) 2019 Authors. This is an open-access article distributed under the terms of the Creative Commons Attribution License, which permits unrestricted use, distribution, and reproduction in any medium, provided the original author and source are credited. 